\title{
PARENTS' ROLE IN MOTIVATING THEIR CHILDREN TO STUDY ENGLISH DURING THE COVID PANDEMIC 19
}

\author{
Khudriyah \\ Prodi Pendidikan Agama Islam, STIT Al Urwatul Wutsqo Jombang \\ e-mail: azkiabilqis@gmail.com
}

\begin{abstract}
This research discusses about parents role to motivate their children to stud English during Corona Virus pandemic. This study is case study in MTs arrohman and MTs al Urwatul Wutsqo Jombang. Using qualitative descriptive, interview and observation as instrument. The data collected by Miles \& Huberman model. This study resulted that parents' role in motivating their children to learn English during pandemic are as educator, motivator, facilitator, and being good models for their children. To do that, they faced some problem, and overcome them by advising patiently, working cooperatively with other parents to prohibit their children from playing while studying, and devide time well. The children motivation to study English depended on the way their parents motivated.
\end{abstract}

Key words: role, motivate, English, pandemic

\section{A. Background of Study}

English is very important because many important sources are written in English. However, many foreign language learners are lazy to lern it, included Indonesian learners. Even in pandemic corona virus. Most students are lazy to learn it. Such reasons as: most teachers using the same media, strategy, technique, that is online and by giving tasks, corrected and giving score, morever, the taeachers who are Luddite.

English as an international language has an important role in this modern world. English functions both to absorb and exchange information, science, and technology in international communication. Because of this, English has an important role in this globalization era; the Indonesian government has decided to include English as one of the compulsory subjects in the national curriculum from the junior to university students. 
The teaching of English in Indonesia is enabling students to use English for communication ${ }^{1}$. This statement is accordance with the objective of teaching English in Indonesia as stated in the decree of the Minister of Education No. 22, 2006 that the objectives of the teaching of English at SMP/MTs are targeted at: (1) developing the students' oral and written communicative competence, (2) making the students have awareness toward the nature and the importance of English to increase the nation competitiveness in the global society, and (3) improving students' understanding about the relationship between language and culture ${ }^{2}$.

However, Covid-19 virus pandemic in Indonesia and even the world has impacted many schools to stop the face-to-face learning process from becoming an online system by utilizing technology that has developed at this time. Related to technology in English learning is how a remote learning system can answer problems that exist in English education in particular. The presence of this pandemic makes all government goal is postponed. Theloses are also experienced by schools, teachers, students, even parents.

Family is the main educational institution. For this reason, parents play an important role in guiding and accompanying children in their lives. Parents have to create conducive environment so their children can show their potential, intelligence and self-confidence. And understand their children development and the potential development their intelligence ${ }^{3}$.

There are many ways to provide education to children both formal and informal. Meanwhile, formal education does not only provide knowledge and skills to their children at school. But it is more to instill values or morals, norms, ideals of behavior and aspirations with the guidance of parents at home. Schools or educational institutions are places for transferring knowledge from teachers to students, in the teaching process sometimes students experience burnout in

${ }^{1}$ Saukah, A. The Teaching of Writing and Grammar in English. Bahasa dan Seni: Jurnal bahasa, Sastra, Seni dan Pengajarannya. 28, 2000, 2, pp.191 - 199.

${ }^{2}$ Depdiknas. Panduan Pengembangan Silabus Mata Pelajaran Bahasa Inggris Sekolah Menengah Pertama. Jakarta: Direktorat Pembinaan Sekolah Menengah Pertama, 2006.

${ }^{3}$ Ma'ruf Zurayk, Aku dan Anakku: Bimbingan Praktis Mendidik. Anak Menuju Remaja, (Bandung, Al Bayan), 1998), 21. 
learning so that it can make a student's reasoning power down and result in decreased achievement. In this case, the motivation of students is very necessary because it can improve the learning quality. Students' motivation can be gained by themselves, it is necessary to have the role of other people in fostering this motivation. The phenomenon is many parents who have no role for their children, even they are more likely to prioritize work and think their role is not important to motivate them ${ }^{4}$.

According to Ridho "Parents are the first teachers who determine children's success. Parents have a sacred task and responsibility in escorting their children to be succeeded. Parents must educate their children in earlier age, provide understanding and knowledge, both about themselves, or their environment" ${ }^{\prime 5}$. In addition, parents must also create their children's personality and morality towards a bright and glorious future. The success of children depends on both parents. Under any circumstances, the child's condition must be accepted as it is, with gratitude to Allah and carry out his mandate as well as possible. Therefore, educating children in every aspect will determine their future. The way to educate parents is very influential on their growth and development in facing external challenges that are very complex and global.

Definition of roles according to Hamalik, is certain patterns of behavior which are characteristic of all officers from a certain job or position ${ }^{6}$. Meanwhile, according to the large Indonesian dictionary the role is a stepping-up of a person's behavior that is expected to be owned person who is in the community ${ }^{7}$. Based on that statement, it can be concluded that role is a pattern of behavior which is a characteristic that a person has as a job or position that is domiciled in the community. In a family, the role of parents is very important for children, especially when the child enters school age and the age of education.

Parents have a role in supporting their children, especially in terms of increasing children's learning motivation, both affective, cognitive, and

${ }^{4}$ Asnawi. Teori Motivasi. (Studio Press: Jakarta, 2012), 1-2.

5 Ridho. Sofi. M. Peran Oang Tua Terbadap Aktivitas Belajar Siswa MTs Al Ishlah Mayang Jember. (Perpustakaan UIN Malang, 2015) 50

${ }^{6}$ Hamalik, Oemar. Psikologi Belajar dan Mengajar. (Bandung: Sinar Baru Algesindo, 2007), 33.

${ }^{7}$ KBBI (Kamus Besar Bahasa Indonesia) Jakarta: PT (Persero) Penerbitan dan Percetakan, 2005).25 
psychological potential $^{8}$. The motivation given is not only in their words, but also other forms their children's enthusiasm and motivation to learn is raised. Such of the parents roles in improving children's learning, are engaging in children's learning activities, paying attention to the child's condition both physically and physically, understanding and overcoming children's learning difficulties and providing adequate learning facilities.

Learning motivation is an encouragement that is able to provide instructions for students to learn and provide direction to students to achieve a learning goal. Students who have high learning motivation tend to show enthusiasm and passion in participating when the learning process occurred. Children will look serious, attentive and active in participating in teaching and learning activities both in and outside classroom. Therefore, as parents must be able to support all forms, so that it can help the children growth and development in continuing formal and non-formal education. The existing of parents support, the children feel more comfortable in learning activities.

Parents role to their children's education are: controlling their learning time and the way they learn, children are taught to study regularly, not only when they get homework from school or will get the tests. Every day children are taught to repeat the lessons they get at school. The existence of complete learning facilities is very supportive for improving children's education, by having adequate facilities will support children's learning development. Children will feel comfortable and motivated to learn at home.

Parents' attention to children's education in the household greatly determines the child's success in learning; this has a positive impact to change their behavior and the development of children's education. Parents pay attention to children's learning at home so that children get good learning achievements at school. Learning difficulties experienced by students cannot be separated from the role of parents in providing guidance at home, paying attention to children in doing assignments, managing children's discipline and so on.

${ }^{8}$ Ningrum. L. K. Peran Orang Tua dalam Meningkatkan Motivasi Belajar Anak di Kelurahan Margorejo 25 Polos Kecamatan Metro Selatan. (Perpustakaan IAIN Metro, 2019), 2-3. 
The role of parents towards this child is often influenced by the attitude of the parents in providing guidance and guidance to the child. Based on the explanation above, it can be understood that learning outcomes of children in school are strongly influenced by the attention, guidance and supervision of parents towards children's learning. Parents must have concern for children's learning at home and try to help children's learning according to their respective abilities. These can motivate their children especially during this pandemic.

Motivation to learn according to Frederick J.Mc Donald, is a change in energy within a person (person) which is marked by the emergence of feelings and reactions to achieve goals ${ }^{9}$. In line with Djamarah, Sardiman said that good motivation in learning will show good results. In the learning process, motivation is needed, because someone who does not have motivation to learn will not be able to carry out learning activities ${ }^{10}$. This is a sign that something that will be done does not meet his needs. Everything that will attract another person's interest will not necessarily interest that particular person as long as it does not come into contact with his need.

Uno, says that learning motivation is an internal and external encouragement for students who are learning to make behavioral changes, generally with several indicators or supporting elements ${ }^{11}$. Means that learning motivation is an impetus that arises both from within and from outside the student, which is able to generate enthusiasm and excitement for learning and provide direction for learning activities so that the desired goals can be achieved. The function of motivation is directional function and activating and energizing function $^{12}$. According to Joclaire dkk in Sardiman, motivation is a subject about which three is ver little, if any, common understanding ${ }^{13}$. This fact is evidenced by the jargon in use today. Yet you would find some terms that are fairly common to motivational literature.

${ }_{9}^{9}$ Djamarah Syaiful Bahri. Psikologi Belajar. (Jakarta: Rineka Cipta, 2011), 148.

${ }^{10}$ Sardiman, Interaksi dan Motivasi Belajar Mengajar, (Jakarta: Raja Grafindo Persada), 2010.

${ }^{11}$ Uno Hamzah B. Teori Motivasi dan Pengukurannya. (Jakarta: Bumi Aksara, 2008), 23.

${ }^{12}$ Nana Syaodih Sukmadinata. Metode Penelitian Pendidikan. (Bandung: Remaja Rosdakarya, 2013), 62

${ }^{13}$ Nana Syaodih Sukmadinata. Metode Penelitian Pendidikan., 78. 
There are two kinds of motivations they are motivation that comes from within person which is called "intrinsic motivation" and motivation that comes from outside of one's self, which is called "extreme motivation". In learning activities, instrumental motivation is needed, especially learning alone. Someone who does not have instristic motivation is very difficult to carry out continuous learning activities. Someone who has instinctive motivation always wants to get ahead in learning. The desire was on the background of positive thinking, that all subjects are needed now will be useful now and in the future. The drive to learn comes from need, which contains the necessity to become an educated and knowledgeable person. So, intrinsic motivation appears based on awareness with an essential purpose, not just attributes and ceremonies.

Extrinistic motivation is the opposite of intrinsic motivation. Extrinsic motivations are active and functional motives due to external stimuli, such as environmental factors that support children to carry out learning activities, namely from the teacher and the child's parents themselves. This motivation is needed when someone does not have intrinstic motivation anymore, so there is a need for an external driving factor. It can be said that extrinistic motivation is needed if the intrinsic motivation does not exist. So this extractive motivation is really needed when a person is no longer has motivation.

\section{B. Research Method}

This research is case study with qualitative approach and the consideration is the researcher wanted to get deepest information about the parents' role in motivating their children to study English during pandemic of corona virus-19. The researcher as instrument, dig the information in the field until all data is fulfilled. Using snowball sampling and the data sources were informants who care their children especially the junior students of MTs ar Rohman and MTs al Urwatul Wutsqo Jombang.

The data collection technique is through interviews and observation. In testing the validity of this research data, researchers used several methods of increasing persistence; reading various book references and research results or documentation related to the findings studied, peer discussion, and triangulation. 
Data analysis was performed using the Miles and Huberman model (data reduction, display, and verification / conlusion drawing) $)^{14}$.

\section{Research Result}

Leraning motivation is an important thing must be owned by students, it makes their achievement will be increased. One of the factors affected students motivation is parents. The teachers are not able to control students to learn when they are at home. This reason make parents' role is important. The result of reasearch about parents' role in motivating their chidren in learning English during pandemic are as follows:

1. Parents Role In Motivating Their Children To Study English During Pandemic

a. As Educator

Educators in Islam are first and foremost parents who are responsible for their students by striving for the development of all the potential of their students, affective potential, cognitive potential and psychomotor potential. As educator, parents from students at MTs arrohman and al Urwatul Wutsqo play out in different ways. And it was done by few parents who have enough education, when they got difficulties in educating their children; they search information from google about how to keep their children study during pandemic. Some of them taught their children based on their experience when they were students. And most of them educated by advising them with religious teachings.

b. As Motivator

During pandemic corona virus, family has a very important role in developing their children's personality to become good students. Due to parents are closer to children than their teacher, most of the students' time is with their parents at home, and the motivation which can be given by them is in the form of gifts, praise and punishment. Based on the

14 J Lexy Moleon, Metodologi Penelitian Kualitatif. (Bandung: Remaja Rosdakarya, 2018), 25 
results of interview, it was stated that when their students are at home, their parents always remind their students to learn, the way parents to motivate them to study is promising them to give something, for example if their score is good then they were give a gift, so that their children study hard and more diligent.

2. The following are the ways are used by parents of students at MTs Arrohman and MTs al Urwatul Wutsqo to motivate their children to study English during pandemic:

a. Keeping Good Relationship Between Parents and Children

Good communication and interaction between parents and children will foster better relationships. Parents' attitude can make children feel reluctant because they are noticed by their parents. Some of the little things that parents of students of MTs Arrohman and MTs al Urwatul Wutsqo to motivate their children to study English have done are asking about children's difficulties in learning, what they need, etc. This is done to maintain social relations with children. Knowing the children's condition can give parents an idea of theeir children's personality and character. Social relationships are also established from good communication between parents and children which will always transmit positive influences and positive emotional connections. On the other hand, if parents are angry or depressed, these emotions will affect their children.

b. Listen to and Appreciate Their New Ideas about How to Study Englsih

Everyone wants to be heard, including children. By giving time to children to listen to their new ideas, proves that parents are authoritative and wise. Good parents provide opportunities for their children to develop creativity through children's new ideas. Every opinion, thought or idea is the result of a thought. Therefore, children's ideas must be respected.

c. Appreciate Their Learning Improvement Though It's Small

As a parent, paying attention to every little improvement in the child's performance or skills is a positive thing that must be done and 
appreciated. Giving appreciation is very important to increase their motivation to learn. Parents should not only ask them in improving their learning result, but they must evaluate it, and appreciate, eventhough the increasing results is only a little.

d. Controlling Them When They Are Studying English

The presence of parents as the important person at home can affect the enthusiasm of learning English for children. Many children are lazy to learn English because they have never been accompanied by their parents, so the impression is that their parents do not care about their learning. They also try to greet their children when they are studying English. In addition, parents also take the time to come to their study room when they are studying English in particular. Besides, their parents do not hesitate to help them when they experience difficulties that really cannot be overcome.

e. Building Trust Between Parent and Children

Trust is principal for a better working relationship, parents can build the trust by prioritizing honesty. Parents never lie or gossip about the lack of children to other family members. This will backfire for parents because their trust towards parents is able to be collapse. In addition, fostering good communication is also a way to build trust. Where there is always a two-way dialogue in fostering their relationship, namely parents listen to their children and vice versa, children will listen to their parents. This is the way parents do, so that trust builds up which makes children even more enthusiastic about learning English.

f. Create a Positive and Fun Learning Atmosphere

Pleasant and comfortable work environment often makes children enthusiastic about learning, especially learning English. In this case, children get encouragement from outside themselves which influences them to stay positive so that they can complete work properly and on time. Their parents make the learning atmosphere more positive by nurturing positive thinking first. Their parents have a positive character and always see that everything has a solution, this is very easy to create a 
positive and fun learning atmosphere to increase students' motivation to learn English.

g. Being Authoritative but Not Stiff

Being parents is an exciting challenge and must be conquered. Children will feel reluctant towards their parents if parents seek ways to be authoritative and wise in making decisions related to children's welfare. Parents should not think that they must always be respected first just because they are everything for the child. Parents also should not be too rigid in making decisions; this can be done by considering the bad consequences that will happen to their children, especially if it affects them on learning motivation.

The research result above is in accordance with the theory of Vitasari that Extrinsic factors are active and functioning motives due to external stimuli. So the extrinsic motivation arises because of an external push. Motivation in studying English activities begins and continues based on an encouragement that is not absolutely related to learning activities. While the forms of extrinsic motivation include: learning for the sake of obtaining the promised material reward, learning to avoid the promised punishment, learning to increase social prestige, learning for the sake of getting praise, studying for guidance in the position held or in order to fulfill the requirements of a promotion.

It is also related to what Sardiman statement that extrinsic motivation is the motivation that comes due to factors from outside the students, such as giving advice from the teacher, gifts (rewards), healthy competence among students, punishment, and so on. Extrinsic motivation is an encouragement for achievement given by others such as encouragement, praise and advice from teachers, parents, etc, so that it can improve student achievement. The success or failure of the motivation given by parents can be seen from the actions of students after facing the motivation given by the parents. 
h. As Fasilitator

Facility was considered as a tool or means of learning only. But in reality the facility can boost motivation to children to study hard, this can be seen in the results of the interview and is getting stronger as a tool that can increase motivation in children with supporting theories. Parents as providing facilities such as a comfortable study room and so on to increase motivation in children.

As facilitators, they add amenities by facilitating their children's educational needs during pandemic. For example buying better android, comfortable place for study, and others, as the following information: "they always fulfill the learning needs of their children, such as buying good android for online learning needs, buying other books to complement children's learning tools". They also sear their place for studying, such as a desk and a lamp for studying so that learning is comfortable".

Another opinion is also said by one of the parents. He said that though it is pandemic, and have no money, he fasilitated his children by fulfilling their needs, such as android, packet pulse, etc. It shows that they are giving high attention to their children. All of those done with aims of motivating their children to study English during pandemic, because they are forbiden to go out in order to braek the chain of spreading Corona virus.

The data above indicate that the role of the students parents in facilitating their learning needs at home can be said has been fulfilled. Though is not very complete, it can provide comfort for students in learning. The incomplete facilities provided by parents could be due to economic constraints. However, it has motivated children to study English harder during pandemic.

The provision of facilities described above is considered reasonable by parents, because in addition to increasing children's motivation in learning, it is appropriate for children to get these facilities. 
The provision of adequate facilities is indeed recommended by experts who research on facilities in learning.

The findings above related to what Peratama said that the role of parents in their children's education: By controlling learning time and children's learning methods. Children are taught to study regularly, not only when they get homework from school or will face tests. Every day children are taught to repeat the lessons they get at school. The existence of complete learning facilities support to improve children's education, with facilities in the form of special learning places at home, adequate learning equipment ranging from books to comfortable learning places, facilities and infrastructure that greatly support children's learning development.

Children will feel comfortable to learn at home with complete and adequate facilities, not only giving motivation to children, being a learning medium for children, no less important is that parents have to prepare important learning facilities for children. So that with the facilities provided by parents to children, it can foster children attitude of enthusiasm and love to study English at home so that the child will be excited to get an education even during pandemic.

i. Being Good Model for Their Children

The following are the results of interview were gained from students parents of MTs arrohman and MTs al Urwatul Wutsqo about how to motivate their children to study English. Some of the parents have English capability, but most of them do not have it. They are:

j. Respecting Childrens' Utterances

Learning to appreciate the efforts, abilities, opinions, and habits of others will help to be happy and successful arround interpersonal life. When people want to be appreciated by others, they must respect others first. The key is to stop focusing only on ourselves and start thinking about other people too. Besides, respecting to everything related to the attitudes and behaviors inherent in parents. 
In line with respecting others, maintaining speech is a difficult matter, because people often say things that offend and even hurt others. It actually comes back to them. The words that are spoken, whether or not it is good, will definitely return to the person who said them. The students of MTs arrohman parents always keep their words to motivate their children. According to their parents, they felt difficult to do so. However it was done to motivate their children, especially to study English and other subject that are difficult for them. By respecting their words not to offend their children. The fact the children have high motivation to study.

k. Giving Real Example

In this case, parents do good things, such as on time in doing wake up, pray, clean the house, cook, work, and so on. Exemplary parenting for children is an influential approach or method and has proven to be the most successful in preparing and shaping and developing the potential of children. The results of interview about good models are: some parents never ask their children to study them selves, they asked their students to study while they are reading al Qur'an or doing their habitual work, for example office assignments. Some of them do their work seriusly though it was done at home. It meant they did not work in the office because of pandemic.

1. Ready to be Evaluated

In this case, parents are ready to become mirrors both for themselves and for others. Conditions like this will have an impact on social life in society, especially their children because their words, attitudes and behavior are in the spotlight and are role model. As result of observation, the researcher saw how few parents are crticized by their children to work better when they complain about a pandemic that is not over, some other to be criticized when their parents complain about difficulty finding money because of their terminating. 
m. Consistence

Consistence means that parents maintain what they utter and what they do. It means that they must be careful to keep their moral integrety. as the results of interviews with several parents of students of MTs arRohman and MTs al Urwatul Wutsqo that they try to conform to what is said and what is done, they try to maintain their morals in order to be good role models. as the results of interviews with several parents who said that for the sake of their children's enthusiasm for learning that they could not do it because of their disability, they would keep what they said and what they did, so that their orders would not be opposed by their children.

The research results are related with 2 elements of the theory of Hidayatullah (2010:43) from the three. They are: Readiness to be assessed and evaluated. Readiness to be assessed means the readiness to be a mirror both for him and for others. This condition will have an impact on social life in society, because their words, attitudes and behavior are in the spotlight and are role models.

The next is having moral integrity. Integrity means what is said and what is done are similar. The essence of integrity lies in the quality of its consistency, which is in the form of commitment and consistency to the profession it carries. From the three opinions above have the same core that exemplary is commendable behavior which should be emulated by others, so it can be concluded that exemplary is an act of cultivating morals by respecting speech, attitudes and behavior so that others can imitate it based on two elements, namely being ready to be assessed and evaluated, and moral integrity. If this has been carried out and familiarized properly from the start, it will have an important meaning in shaping character as educating parents.

n. Parents' Barriers To Motivate Chidren

The obstacles faced by parents to mativate their chldren are environment and electronic media broadcasts. It has an impact when parents motivate children to learn. As the following statement: Nek wes 
kadung kenek vidio game kon sinau angel pokoe, nopo malaeh wanyahe bahasa Inggris (When they play online games, they feel heavy in learning, even English, because they keen on playing games), the next statemen is: tha menawi kepegelen biasane wonten mawon alesanipun, (if they feel tired they always make excuses), the other statement is: yugo kulo niku nek wancinipun bahasa Inggris, niku gelek ten kamar kyambean alasanipun sinau, tibake e tilem, ngeten niku nek. dikengken sinau mboten purun alesane angel (when the time to learn English comes, they are often in the room alone with the excuse of studying, but they sleep, and when they are forced to learn English they refuse, the reason is English is difficult. The obstacles faced also come in the environment, which is usually from peers who play during children's study hours; therefore parents must be smart in dividing their time when to give play time and when to study.

To overcome these problems, the parents always give them advice patiently: threatening the child not to buy more credit, or having the android confiscated. The parents are also work cooperatively with other parents to prohibit their children from playing while studying. The time division carried out by parents and the directions is intended so that children do not feel tired and distracted by their concentration while studying. The constraints described researcher by looking at the real situation in the field.

Parents' attention to children's education in the household greatly determines the child's success in learning; this has a positive impact on changes in behavior and the development of children's education. Parents pay attention to children's learning at home so that children get good learning achievements at school. Learning difficulties experienced by students cannot be separated from the role of parents in providing guidance at home, paying attention to children in doing assignments, managing children's discipline and so on. The role of parents towards this child is often influenced by the attitude of the parents in providing guidance and guidance to the child. Based on the 
explanation above, it can be understood that the learning outcomes of children in school are strongly influenced by the attention, guidance and supervision of parents towards children's learning. Parents must have concern for children's learning at home and try to help children's learning according to their respective abilities.

o. The students' Motivation to Study English

Motivation is important by having high motivation, they will be motivated to learn and do their tasks. This is inseparable from the intervention of parents who are in charge of maintaining motivation and providing motivation when children lose their enthusiasm for learning. Based on the research result, it can be seen that from 25 parents were interviewed about children motivation to study English both at MTs arrohman and MTs al Urwatul Wutsqo can be concluded that the parents who motivated their children well, resulted children with high motivation in learning English, on the other hand, those who are not motivating children well, resulted students are lazy to study English, because English is difficult to manage during pandemic or by online learning.

\section{Conclusion}

Based on the finding and discussion above, it can be concluded that parents role in motivating their children to learn English during pandemic are as educator, motivator, facilitator, and being good models for their children. These are done to motivate them in studying all subject especially English lessons. To overcome the problems faced, they advising them patiently, working cooperatively with other parents to prohibit their children from playing while studying, and devide time well. The children motivation to study English based on the way their parents motivated. 


\section{BIBILIOGRAPHY}

Asnawi. Teori motivasi. Studio Press: Jakarta. 2012.

Depdiknas. Panduan Pengembangan Silabus Mata Pelajaran Bahasa Inggris Sekolah Menengah Pertama. Jakarta: Direktorat Pembinaan Sekolah Menengah Pertama. 2006.

Djamarah, Syaiful Bahri. Psikologi Belajar. Jakarta : Rineka Cipta. 2011.

Hamalik, Oemar. Psikologi Belajar dan Mengajar. Bandung: Sinar Baru Algesindo. 2007.

Hidayatullah. Pengaruh Kepemimpinan Kharismatik dan Non Kharismatik Terhadap Kinerja Ditinjau dari Motivasi Pegawai Negeri Sipil (Didinas Kesehatan Kab. Kutai Kartanegara). Perpustakaan.uns.ac.id. 2010.

KBBI (Kamus Besar Bahasa Indonesia). Jakarta: PT (Persero) Penerbitan dan Percetakan. 2005.

Ma'ruf zurayk, Aku dan Anakku : bimbingan praktis mendidik anak menuju remaja, Bandung, Al Bayan. 1998.

Miles, Matthew B. \& A. Michael Huberman. 2009. Analisis Data Kualitatif. Jakarta: UIPress.

Moleong. J Lexy, Metodologi Penelitian Kualitatif. Bandung: Remaja Rosdakarya, 2018.

Ningrum. L. K. Peran Orang Tua dalam Meningkatkan Motivasi Belajar Anak di Keluraban Margorejo 25 Polos Kecamatan Metro Selatan. Perpustakaan IAIN Metro. 2019.

Ridho. Sofi. M. Peran orang Tua Terhadap Aktivitas Belajar Siswa MTs Al Ishlab Mayang Jember. Perpustakaan UIN Malang. 2015.

Sardiman, Interaksi dan Motivasi Belajar Mengajar, Jakarta: Raja Grafindo Persada, 2010.

Saukah, A. The Teaching of Writing and Grammar in English. Bahasa dan Seni: Jurnal Bahasa, Sastra, Seni dan Pengajarannya. 2000

Sukmadinata, Nana Syaodih. Metode Penelitian Pendidikan. Bandung: Remaja Rosdakarya. 2013

Uno, Hamzah B. Teori Motivasi dan Pengukurannya. Jakarta: Bumi Aksara. 2008. 